ARE AUSTRALIAN TEACHERS MAKING THE GRADE? A STUDY OF NEWS COVERAGE OF NAPLAN TESTING

by

Kathryn Shine

Department of Journalism, Curtin University, Perth, Western Australia

k.shine@ curtin.edu.au 


\title{
ARE AUSTRALIAN TEACHERS MAKING THE GRADE? A STUDY OF NEWS COVERAGE OF NAPLAN TESTING
}

\begin{abstract}
The standardised testing of school children has been the subject of significant news media attention in recent years in many developed countries around the world. This paper examines the reporting of annual National Assessment Program Literacy and Numeracy (NAPLAN) tests in three major Australian newspapers, with a particular focus on the portrayal of schoolteachers in the coverage. Overall, teachers were presented as strongly opposed to NAPLAN and the publication of test results, yet the newspapers themselves supported the tests as an important accountability measure. Teachers were depicted as trying to influence the testing system through teaching to the test and cheating. They were presented as generally inadequate as teachers and were blamed for perceived failings in the educational system. These findings point to implications for teacher recruitment and retention, and for journalism education and training.
\end{abstract}




\section{Introduction}

Schools and schoolteachers are frequently the subject of news media attention in developed countries around the world. Research has shown such education-related reporting often concentrates on standards (Cohen, 2010; Stack, 2006; Thomas, 2006; Warmington and Murphy, 2004) and particularly, in recent years, on the results of large-scale testing of school children, which has been introduced in countries including the United States, Canada and the United Kingdom. The situation in Australia - where one million school students sit three tests over the course of a week every year - is no different. News media coverage of the controversial National Assessment Program Literacy and Numeracy (NAPLAN) tests is extensive, particularly in metropolitan daily newspapers. This study examines recent reporting of NAPLAN in three major Australian newspapers, concentrating on the way schoolteachers were portrayed throughout the coverage.

The focus is on schoolteachers because research on news coverage of education has typically considered the way educational issues, particularly issues relating to policy, have been reported. Findings about the portrayal of schoolteachers in the news media have tended to be absent from, or peripheral to, such research. Recognising this, researchers have called for more attention to be focused on the representation of schoolteachers (Hargreaves et al, 2007: 20; Thomas, 2006: 312) in news media. This is necessary, they say, because news media coverage is known to strongly influence educational policy (Lingard and Rawolle, 2004: 63; Thomson, 2004: 252) as well as public perceptions about schools and teachers (Cohen, 2010: 106; Stack, 2006: 65, Warburton and Saunders, 1996: 308). Teachers themselves have acknowledged this influence, reporting that news media coverage can affect their 
relationships with their friends, families and the wider community (Blackmore and Thorpe, 2003: 582).

\section{Background}

The standardised testing of school children has been a contentious issue in Australia since it was first introduced in 1998. Initially, each state devised its own tests for students in years 3,5 and 7 but that system changed after 2007 when Education Ministers from each state agreed to work together to conduct national literacy and numeracy testing for years 3, 5, 7 and 9. The following year, all Australian students in those year levels were assessed, for the first time, on the same tests in literacy and numeracy. These tests were known as National Assessment Program Literacy and Numeracy, and thereafter as NAPLAN. Teacher unions opposed the introduction of NAPLAN and teachers in various states have regularly threatened to boycott the administration of the tests (Shine and O'Donoghue, 2013: 121). Despite strong protests from teachers, the Federal Government decided to make the NAPLAN results public in 2010 when it launched its 'myschool' website. In recent years, it has been claimed that the publication of the results has led to NAPLAN becoming "highstakes" testing; placing teachers and students under significant pressure to ensure their school performs well. Such concerns led to the issue being referred to the Australian Senate Education, Employment and Workplace Relations Committee in May 2013 and an inquiry began. An interim report was published in June 2013, and this will be the subject of later discussion.

\section{Methodology}

This paper identifies key representations of schoolteachers from the coverage of NAPLAN in three metropolitan daily newspapers, The Sydney Morning Herald, The 
West Australian and the Herald Sun, over three and a half years; between January 1, 2010 and June 30, 2013. This time period was chosen because the NAPLAN test results were made public via a website called 'myschool' from January 2010. The analysis considers articles published until June 30, 2013, so as to include the reporting of the round of tests in May 2013.

The three newspapers chosen represent a cross-section of the Australian print news sector. The Fairfax-owned The Sydney Morning Herald has a strong tradition as a broadsheet publication (although its format was changed to tabloid towards the end of the time period considered in this study, in March 2013). The Melbourne-based Herald Sun is a high-circulation tabloid newspaper while The West Australian, the only daily newspaper in Western Australia, is considered a broadsheet/tabloid hybrid. The newspapers are from three states - New South Wales, Victoria and Western Australia - and are owned by three different companies, News Ltd, Fairfax and Seven West Media.

The articles analysed for this study were drawn from a Factiva database search for the term 'NAPLAN' in The Sydney Morning Herald, the Herald Sun and The West Australian. The search identified a total 454 articles across the three papers with the highest number appearing in The Sydney Morning Herald (248), followed by the Herald Sun (125) and The West Australian (81). All the articles were published in the paper editions of the newspapers. Most of the news articles were also published on the newspapers' websites.

The coverage included news, features, opinion and editorial pieces. The focus of the analysis was on the headlines and accompanying text and not on any photographs or illustrations that may have accompanied them. The analysis was 
confined to those articles that directly referred to teachers, which comprised about two-thirds of the total coverage.

To examine the newspapers' depiction of schoolteachers in their coverage of NAPLAN, a modified version of grounded theory was used. The grounded theory approach, introduced by Glaser and Strauss (1967) and later developed by Strauss and Corbin (1990), involves the use of a systematic set of procedures to code data into categories to identify patterns (Weerakkody, 2009: 281). This process allows for the development of inductively derived theory.

A traditional grounded theory approach involves open coding, axial coding and selective coding. However, because a modified grounded theory approach was adopted for the analysis in this study, only the first of these processes, open coding, was used. This involved first reading the collection of NAPLAN articles from each newspaper in its entirety several times. The articles were then examined line-by-line to "define the actions and events" (Charmaz, 2003: 259) within them. The intention was to "interact with and pose questions to the data," as described by Charmaz (2003: 258) while at the same time making constant comparisons (Dey, 2004: 87). Building on this process, various patterns and themes were identified, as was change over time. Memos, the "running logs of analytic thinking," (Corbin and Strauss, 2008: 108) were also used to explore ideas emerging from the data, which in turn led to the development of a series of propositions about the newspapers' portrayal of schoolteachers in their coverage of NAPLAN.

As the study was conducted within the interpretivist paradigm it should be evaluated in terms of 'trustworthiness', as opposed to the more positivist criteria of validity and reliability. The components of trustworthiness are credibility, transferability, dependability and confirmability (Maykut and Morehouse, 1994: 146). 
Credibility is enhanced when strategies are put into place that check on the inquiry process and allow for the direct testing of findings and interpretations from the original sources (Merriam, 2009: 215). To this end, the reader can consult the newspaper accounts. Transferability to other contexts (within Australia) has been addressed with the inclusion of publications based in three different Australian states. And finally, the development of an 'audit trail' is an accepted strategy for ensuring both dependability and confirmability (Birks and Mills, 2011: 38). In this regard, the author has kept detailed records of the analysis, including coding, memos, drafts of generalisations and propositions.

\section{Analysis}

The analysis undertaken here begins in January 2010 when the myschool website was about to be launched. Although there were some differences in the coverage between the newspapers, four propositions about schoolteachers emerged as strong themes across all three publications. These are: 1) Teachers oppose testing and the publication of results; 2) Teachers should be accountable to the public; 3) Teachers will teach to the test and cheat to influence test results; and 4) Teachers and schools are failing Australian students. Each of these will now be considered in detail.

\section{Teachers oppose testing and the publication of results}

The NAPLAN coverage across the three newspapers repeatedly conveyed the message that teachers had concerns about standardised testing. In particular, teachers were shown to oppose the publication of test results. Teachers were portrayed as opposed to testing and/or the publication of test results in 76 of the articles analysed, 36 of which appeared in The Sydney Morning Herald, 26 in the Herald Sun and 14 in The West Australian. 
At the start of the coverage, in 2010, all three newspapers reported that teachers had threatened to boycott administering the tests in May in protest at the Federal Government's decision to publish the results on the myschool website. Teachers, it was reported, were worried the information on myschool would be used to create league tables that could be used to compare schools. The Australian Education Union president Angelo Gavrielatos, who was quoted in The West Australian on the same matter, told The Sydney Morning Herald in January 2010 that teachers viewed league tables as "one of the greatest threats to the provision of quality education in the history of Australia" (Patty, 2010a: 2). School principals quoted in the newspapers were also shown to consider the publication of results as damaging to schools and students. For example, an article in the Herald Sun quoted a principal as saying: "This has had an extremely negative impact. We have lost students from our school because of the league tables" (Masanauskas, 2010a: 21).

The coverage indicated that teachers opposed the publication of NAPLAN results because it put them under significant pressure to ensure their students (and schools) performed well. The sense that NAPLAN and myschool were creating stress for teachers was conveyed in articles published throughout the three and half years analysed. One such article claimed school principals were "pressured to improve this year's NAPLAN test results at all costs" (Masanauskas, 2010b: 4) while in another report the head of the Western Australian primary school principal's association was quoted as saying teachers were under "massive pressure" to obtain good test results. He went on to say: "Everything now revolves around the NAPLAN tests. It's like Year 12 for Year 3s" (Hiatt, 2012: 1). An article of a similar nature claimed teachers were resisting taking years 3 and 5 classes to "avoid the stress of NAPLAN" (Hosking, 2013: 19). Other key spokespeople in the education sector, such as 
academics, commentators and government officials, generally reinforced the claim that testing was adversely affecting teachers. This was made clear in an article in The Sydney Morning Herald which said "many education leaders" believed NAPLAN had evolved into a "high stakes test that grips schools in nervous tension from the start of the second term" (Stevenson, 2012: 10).

\section{Teachers should be accountable to be the public}

Although the three publications frequently reported that teachers were opposed to and concerned about testing and the publication of results, the newspapers themselves articulated a different view about NAPLAN. Through editorials the newspapers supported the annual tests as an important accountability measure for schools and teachers. The Herald Sun described NAPLAN as an "invaluable guide to parents on their children's educational progress" (14 March 2013: 30), while The West Australian argued NAPLAN was "the best gauge we have of academic standards of our schools" (20 December 2012: 22). The papers also published comments from the Prime Minister Julia Gillard and the Education Minister Peter Garratt who consistently defended the tests and the publication of results on the basis that the education system needed to be more transparent and accountable.

Through editorials, the newspapers argued parents had a right to information about their child and their school, and questioned the reasoning behind resistance to the tests. The Sydney Morning Herald claimed teachers did not like the "scrutiny" (27 November 2012: 10) associated with the testing and that teachers feared the "consequence of measured, comparative performance between schools" (30 April 2012: 10) while The West Australian said teacher unions had run "scare campaigns" (14 May 2013: 20) about NAPLAN. The newspapers acknowledged teacher criticisms of NAPLAN but they maintained that teacher accountability was ultimately more 
important. By the end of the coverage, the newspapers were overtly criticising teachers for undermining the testing process and urging them to co-operate fully with the Federal Government (The West Australian, 14 May 2013: 20). In total, 16 articles included the argument that teachers should be accountable to the public. The Sydney Morning Herald published eight, the Herald Sun five and The West Australian three. Most of these were editorials.

\section{Teachers will teach to the test and cheat to influence test results}

A strong theme to emerge from the coverage across the three newspapers was that teachers were using various methods to influence testing results. This was evident in 62 articles - 21 from The Sydney Morning Herald, 27 from the Herald Sun and 14 from The West Australian. One method being used by teachers was to "teach to the test", according to comments made by union officials, parents, academics and teachers themselves. This message was reinforced in editorials such as one published in the Herald Sun, which said "a high percentage of teachers", admitted they were teaching to the test (27 November 2013: 22). Furthermore, the reporting overall indicated that teaching to the test had been happening for some time. An article published in early 2010 in The Sydney Morning Herald claimed teachers had "long argued" NAPLAN encouraged schools to "teach to the tests" (Patty, 2010b: 15).

Teachers were also shown to be encouraging certain less academic students to stay home and not sit the tests. According to the Herald Sun, several parents and teachers had told the paper of schools that had put "pressure on children to stay home and not 'drag down' the school averages," (Lamperd and Harris, May 2010: 7). Another report said a principal had been "recorded on tape" questioning whether it was a good idea for a struggling student to sit the tests (Masanauskas, 2010d: 15). The other two newspapers published made similar claims. These included an editorial in 
The West Australian which referred to teachers "excluding some of the lower academic achievers" from the tests (14 May, 2013: 20) and an article from The Sydney Morning Herald which said there were signs teachers were "decreasing student participation rates" (Patty, 2011a: 3).

It was claimed that some teachers were willing to go further to improve test results, through cheating the system. This was first raised in The Sydney Morning Herald in February 2010 (Patty, 2010b: 15) and then in the Herald Sun in May of that year, when it was reported that a teacher was being investigated for allegedly helping a student in a numeracy test (Masanauskas, 2010c: 2). Subsequently, all three newspapers reported incidents of alleged cheating and security breaches relating to NAPLAN. For example, The West Australian referred to cases of teachers cheating NAPLAN in articles published in January, May and December 2012.

\section{Teachers and schools are failing Australian students}

The message that teachers and schools were failing Australian students was the dominant theme in the coverage analysed. All three newspapers published articles that explicitly stated the standard of education at Australian schools was declining, as well as many articles that implied the education provided at Australian schools was inadequate. There were 82 articles of this nature among the coverage, including 45 from The Sydney Morning Herald, 18 from the Herald Sun and 19 from The West Australian.

A high number of the negative comments were published in response to the release of NAPLAN or international test results, which the newspapers typically interpreted as showing some deficiencies on the part of the public education system. For example, when reporting the NAPLAN results in September 2011, The Sydney Morning Herald said the performance of junior high school students had slipped 
compared to the previous year (Patty, 2011b: 3). Similarly, the following September, it claimed the 2012 results showed most NSW students had "gone backwards" in reading, spelling and numeracy over the past five years (Browne, 2012: 9). In response to the release of the testing results in September 2010, the Herald Sun reported numeracy and literacy standards had dropped in some areas "despite a big investment by the State Government" (Masanauskas, 2010d: 15), while The West Australian tended to focus on the finding that WA students typically lagged behind their eastern states counterparts (Tillett and Hiatt, 2010: 1). The newspapers all reported on individual schools that had performed well in the tests or had seen significant improvements in results, but such schools were portrayed as exceptions, rather than the norm.

Politicians and other commentators were regularly quoted in the newspapers reinforcing the message that Australian schools and teachers were failing their students. The Prime Minister Julia Gillard and Education Minister Peter Garratt frequently referred to poor testing results when arguing that the Australian public school system needed significant reform in the wake of the Gonski review which had recommended a $\$ 5$ billion funding boost for the sector (see for example Hall, 2012: 6). The coverage also included quotes from various educators and commentators who emphasised the importance of quality teaching. However, the number of references to the need to increase funding to education and set "higher standards" for teachers (Milburn, 2012: 14) conveyed a clear message that Australian teachers and schools were not good enough. Contributors reiterated this in some strongly worded opinion articles, such as one published in the Herald Sun that said "one reason for slipping standards is the quality of candidates attracted to teaching” (Panahi, 2012: 26). 


\section{Discussion}

The Sydney Morning Herald devoted the most attention to NAPLAN, publishing about twice as many stories about the testing system as the Herald Sun and three times as many as The West Australian. Many of the news articles published in The Sydney Morning Herald were written by Anna Patty and a high proportion of the stories published in the Herald Sun were written by John Masanauskas as these were the specialist education reporters for those publications for most of the time period considered. The Sydney Morning Herald coverage was the most diverse in terms of the range of people who were interviewed about or commented on NAPLAN, and included the highest number of quotes from people who supported teachers and were against NAPLAN. Yet, somewhat surprisingly for a publication typically characterised as left-leaning, it was the most critical of teachers who opposed NAPLAN and the publication of test results.

Overall, the coverage of NAPLAN in the three newspapers was similar, despite their geographical and style differences. The newspapers published comments from sources strongly opposed to NAPLAN yet the reporting rarely questioned the validity of the testing results. The tests were presented as an important and accurate measure of student performance, in line with the findings of related research on media coverage of testing conducted in Australia (Mockler, 2012: 9) and Canada (Stack, 2006: 64). Much of the coverage was repetitive, particularly that which related to the release of testing results. This finding is consistent with research on the reporting of annual A level test results in the United Kingdom which found both broadcast and print coverage "predictable, simplistic, ritualistic, and based upon long-established media templates" (Warmington and Murphy, 2004: 296). 
Research on the reporting of the introduction of standardised testing in Australia has found that teachers were portrayed as strongly opposed to testing and the publication of test results (Shine and O'Donoghue, 2013: 131-132). Teaching to the test was shown as common practice in the reporting, even from the outset (Shine and O'Donoghue, 2013: 134). At that time, between 1997 and 2001, the message that teachers were willing to cheat the system was not evident in the reporting. Hence, a new element has emerged in the coverage in more recent times. This finding is supported in other recent research on the effects of NAPLAN (Thompson and Cook, 2014: 129) that argues teachers increasingly have to "manipulate" NAPLAN results in an environment where "only the data counts".

The coverage in the three Australian newspapers was relatively balanced. A broad range of stakeholders was interviewed, including school principals. Nevertheless, the tone of the coverage was predominantly negative, with a strong focus on inadequate educational standards. This focus on a perceived decline in standards has been identified in other education-related news coverage from Australia, the United Kingdom and the United States (Cohen, 2010; Thomas, 2006; Warmington and Murphy, 2004). Furthermore, other studies of news coverage of education have found the reporting conveyed the message teachers were to blame for these deficiencies (Keogh and Garrick, 2011: 428; Thomas, 2006: 299) and, in some cases, that teachers could not be trusted and should be held to account (Cohen, 2010: 116; Mockler, 2012: 6).

\section{Conclusion}

NAPLAN testing has been, and continues to be, the subject of intense news media attention and is increasingly changing the education landscape, to the point that it is "becoming the most important vehicle" (Thompson and Cook, 2014: 139) by which 
Australian teachers represent their teaching. Given the emphasis placed on NAPLAN and its influence on teachers, students and the wider community, it an important subject for research. While some other studies have considered the reporting of standardised testing (Shine and O’Donoghue, 2013; Stack, 2006; Warmington and Murphy, 2004) this is the first Australian research to focus on the portrayal of teachers in the reporting of NAPLAN in multiple publications over a number of years. Findings about the predominantly negative nature of the coverage and the sense of blame directed at teachers and schools suggest the need for further related research to be undertaken. It would be valuable, for example, to expand the study to include all daily metropolitan newspapers in Australia and/or to compare the depiction of teachers in print coverage of NAPLAN to mainstream television and radio reporting of testing. The findings also point to implications for teacher recruitment and retention and journalism education and training.

The NAPLAN coverage analysed for this study repeatedly referred to the need to attract higher quality candidates into teaching, while at the same time consistently questioned educational standards, criticised teachers and schools and portrayed teaching as a high-pressure and stressful job. Such coverage does not present teaching as a job in a favourable light and may deter prospective candidates from entering the profession. Furthermore, news coverage of testing, which has grown cumulatively (Warmington and Murphy, 2004: 289), may be adding to the "high stakes" nature of such tests and the associated stress and pressure for educators, who are known to be resigning in high numbers (Fetherston and Lummis, 2012: 2). This argument is supported by the interim report from The Senate Inquiry into NAPLAN which found that "it may not be NAPLAN itself that causes stress but rather the influence of 
parents, schools and, in particular, the media" (Senate Education, Employment and Workplace Relations Committee, 2013: 10).

Journalists and journalism students should be made aware of the tendency to negative representations of teachers, teaching and schools in reporting on NAPLAN, and recognise that such coverage can influence public perceptions. They should also be informed of the prevalence of simplistic coverage of this complex issue, and encouraged to adopt a more nuanced approach. Given that journalists are known to face significant time pressures it may be beneficial to develop a suitable guide on reporting of NAPLAN testing, including suggestions of relevant people and organisations to contact for comment, a summary of the research on standardised testing, and advice on interpreting test results.

The study also reinforces the importance of educators working with journalists. Educators can be reluctant to co-operate with the news media and teachers, particularly, lack a strong voice in news coverage (Cohen, 2010: 107; Shine and O'Donoghue, 2013: 233; Thomas, 2006: 310). This and other research (Cohen, 2010: 116; Warmington and Murphy, 2004: 297) argues teachers, principals and educational experts should be encouraged to develop a better understanding of the news media and engage with journalists to help present a more balanced and informed image of schools, teaching and teachers. 


\section{REFERENCES}

Birks, M. and Mills, J. 2011, Grounded Theory: A Practical Guide, Sage Publications: London.

Blackmore, J. and Thorpe, S. 2003, 'Media/ting change: The print media's role in mediating education policy in a period of radical reform in Victoria, Australia', Journal of Education Policy, vol. 18, no. 6: pp. 577-595.

Browne, R. 2012, 'Students go backwards in national test scores', The Sydney Morning Herald, 15 September, p. 9, accessed August 2013 from Factiva.

Charmaz, K. 2003, 'Grounded theory: Objectivist and constructivist methods,' in N. Denzin and Y. S. Lincoln (eds), Strategies of Qualitative Inquiry, California, Sage Publications, pp. 249-291.

Cohen, J.L. 2010, 'Teachers in the news: A critical analysis of one US newspaper's discourse on education 2006-2007', Discourse: Studies in the Cultural Politics of Education, vol. 31, no. 1, pp.105-119.

Corbin, J. and Strauss, A. 2008, Basics of Qualitative Research: Techniques and Procedures for Developing Grounded Theory, $3^{\text {rd }}$ edition, Sage Publications, California.

Dey, I. 2004, 'Grounded Theory', in Qualitative Research Practice, in C. Seale, G. Gobo, J. F. Gubrium, and D. Silverman (eds), Sage Publications, London, pp. 80-93.

Fetherston, T. and Lummis, G. 2012, 'Why Western Australian secondary teachers resign', Australian Journal of Teacher Education, vol. 37, no. 4, pp.1-20.

Glaser, B. and Strauss, A. 1967, The Discovery of Grounded Theory, Aldine, Chicago.

Hall, B. 2012, 'Garrett pushes for reforms to improve "shameful" results', The Sydney Morning Herald, 24 May, p. 6, accessed August 2013 from Factiva.

Hargreaves, L., Cunningham, M., Hansen, A., McIntyre, D., Oliver, C. and Pell, T. 2007, The Status of Teachers and the Teaching Profession in England: Views from Inside and Outside the Profession, University of Cambridge Faculty of Education, Cambridge.

Hiatt, B. 2010, 'School heads want test safeguards', The West Australian, 11 June, p.17, accessed August 2013 from Factiva.

Hiatt, B. 2012, 'Teachers caught cheating NAPLAN', The West Australian, 12 January, p.1, accessed August 2013 from Factiva.

Herald Sun 2013, 'Editorial', 27 November, p. 22, accessed August 2013 from Factiva.

Herald Sun 2013, 'Naplan passes test', 14 March, p.30, accessed August 2013 from Factiva.

Hosking, W. 2013, 'Teachers dodge classes', Herald Sun, 14 June, p. 19, accessed August 2013 from Factiva.

Keogh, J. and Garrick, B. 2011, 'Creating catch 22: Zooming in and zooming out on the discursive constructions of teachers in a news article', International Journal of Qualitative Studies in Education, vol. 24, no. 4, pp. 419-434.

Lamperd, R. and Harris, A. 2010, 'Stay home if you can't make the grade', Herald Sun, 12 May, p.7, accessed August 2013 from Factiva.

Lingard, B. and Rawolle, S. 2004. 'Mediatizing educational policy: The journalistic field, science policy, and cross-field effects', Journal of Education Policy, vol. 19, no. 3, pp. 361-380. 
Masanauskas, J. 2010a, 'Bullies use school league tables to taunt Students' Herald Sun, March 25, p. 21, accessed August 2013 from Factiva.'

Masanauskas, J. 2010b, 'NAPLAN pressure left anxious kids in tears', Herald Sun, 11 June 11, p. 4, accessed August 2013 from Factiva.

Masanauskas, J. 2010c, 'Teacher "helped" student', Herald Sun, 19 May, p. 2, accessed August 2013 from Factiva.

Masanauskas, J. 2010d, 'Principal under fire', Herald Sun, 13 May, p. 15, accessed August 2013 from Factiva.

Maykut, P. and Morehouse, R. 1994, Beginning Qualitative Research: A Philosophic and Practical Guide, Falmer Press: London.

Merriam, S. 2009, Qualitative Research: A Guide to Design and Implementation, Jossey-Bass: San Francisco.

Milburn, C. 2012, 'Lessons learnt: 13 years may not be enough', The Sydney Morning Herald, 10 September, p. 14, accessed August 2013 from Factiva.

Mockler, N. 2012, 'Reporting the 'education revolution': Myschool.edu.au in the print media', Discourse: Studies in the Cultural Politics of Education, vol 31, no.1, pp.1-16.

Panahi, R. 2012, 'Underqualified, underworked and overpaid', Herald Sun, 22 August, p. 26, accessed August 2013 from Factiva.

Patty, A. 2010a, 'Teachers united in league table boycott', The Sydney Morning Herald, 20 January 20, p.2, accessed August 2013 from Factiva.

Patty, A. 2010b, 'Reading, writing and number crunching', The Sydney Morning Herald, 8 February, p. 15, accessed August 2013 from Factiva.

Patty. A. 2011a, 'NAPLAN style testing has "failed" US schools', The Sydney Morning Herald, 2 May, p. 3, accessed August 2013 from Factiva.

Patty, A. 2011b, 'Test scores show NSW pupils are struggling', The Sydney Morning Herald, 10 September, p. 3, accessed August 2013 from Factiva.

Senate Education, Employment and Workplace Relations Committee June 2013, 'Effectiveness of National Assessment Program - Literacy and Numeracy Interim Report', Senate Printing Unit: Parliament House, Canberra.

Shine, K. and O'Donoghue, T. 2013, Schoolteachers in the News, Cambria Press, New York.

Stack, M. 2006, 'Testing, testing, read all about it: Canadian press coverage of the PISA results', Canadian Journal of Education, vol. 29, no. 1, pp. 49-69.

Stevenson, A. 2012, 'Warnings on NAPLAN misuse', The Sydney Morning Herald, 12 May, p. 10, accessed August 2013 from Factiva.

Strauss, A. and Corbin, J. 1990, Basics of Qualitative Research: Grounded Theory Procedures and Techniques, Sage Publications, Newbury Park, California.

The West Australian 2012, 'NAPLAN needs full support of schools to Work', 20 December, p. 22, accessed August 2013 from Factiva.

The West Australian 2013, 'There should be no need for NAPLAN stress', May 14, p.20, accessed August 2013 from Factiva.

The Sydney Morning Herald 2012, 'School tests need close watch', 30 April, p.10, accessed August 2013 from Factiva.

The Sydney Morning Herald 2012, 'A lesson for teachers from their least-loved exam', 27 November, p. 10, accessed August 2013 from Factiva. 
Tillett, A. and Hiatt, B. 2010, 'Schools fees, grants will be added to the new website', The West Australian, 29 January, p. 1, accessed August 2013 from Factiva.

Thomas, S. 2006, Education Policy in the Media: Public Discourses on Education, Post Pressed, Teneriffe.

Thompson, G. and Cook, I. 2014, 'Manipulating the data: Teaching and NAPLAN in the control society', Discourse: Studies in the Cultural Politics of Education, vol. 35, no. 1 , pp. 129-142.

Thomson, P. 2004, 'Introduction', Journal of Education Policy, vol. 19, no. 3, pp. 251-252.

Warburton, T. and Saunders, M. 1996, 'Representing teachers' professional culture through cartoons', British Journal of Educational Studies, vol. 44, no. 3, pp. 307-325. Warmington, P. and Murphy, R. 2004, 'Could do better? Media depictions of UK educational assessment results', Journal of Education Policy, vol. 19, no. 3, pp. 285299.

Weerakkody, N. 2009, Research Methods for Media and Communication, Oxford University Press, South Melbourne. 
Word count: 5304 including abstract and references 